\title{
PERSEPSI DOSEN TERHADAP PENGGUNAAN ICT DALAM PEMBELAJARAN BAHASA INGGRIS
}

\author{
Sari Puspita Dewi ${ }^{1)}$, Abdul Azis Abdillah ${ }^{2)}$ dan Nidia Sofa ${ }^{3)}$ \\ ${ }^{1}$ Jurusan Teknik Grafika dan Penerbitan, Politeknik Negeri Jakarta \\ ${ }^{2}$ Jurusan Teknik Mesin, Politeknik Negeri Jakarta \\ ${ }^{3}$ Jurusan Administrasi Niaga, Politeknik Negeri Jakarta \\ E-mail: ${ }^{1}$ Sari.puspitadewi@grafika.pnj.ac.id
}

\begin{abstract}
Abstrak
Studi ini dilaksanakan untuk mengetahui bagaimana persepsi dosen terhadap penggunaan teknologi digital, yang biasa disebut information \& communication technology (ICT), pada pembelajaran bahasa Inggris yang digunakan oleh dosen kepada mahasiswa. Metode penelitian yang digunakan adalah metode kualitatif dengan data kuantitatif. Dalam proses pengumpulan data, penulis menggunakan dua perangkat penelitian berupa kuesioner, dan wawancara terhadap dosen bahasa Inggris di PNJ. Pengkajian ini dilakukan dengan mengumpulkan informasi terkait persepsi dosen terhadap penggunaan ICT, dan juga mengidentifikasi kendala dalam penggunaan ICT pada pembelajaran bahasa Inggris. Hasil penelitian menunjukkan 100\% responden setuju bahwa pengajaran bahasa Inggris sangat cocok dipadukan dengan ICT, juga setuju bahwa penggunaan ICT juga dapat membuat pembelajaran menjadi sangat menyenangkan. Sedangkan, terkait kegunaan ICT bagi Mahasiswa, 18\% responden tidak setuju dengan manfaat pengajaran ICT yang akan mempermudah mahasiswa dalam mendapatkan pekerjaan (yang layak) dimasa yang akan datang. Selain itu juga, 15 hingga 25\% responden juga tidak setuju bahwa pembelajaran menggunakan ICT dapat membantu mahasiswa memahami materi secara mendalam, kemudian meningkatkan nilai bahasa Inggris, dan membantu mahasiswa dalam berkomunikasi. Namun, terdapat beberapa kendala ditemukan secara intrinsik dan ekstrinsik. Kendala yang dialami dosen paling besar merupakan kompetensi dosen dalam menggunakan ICT sekaligus juga pengalaman-pengalaman buruk yang pernah dialami dosen dalam penggunaan ICT dalam kelas. Pada kendala ekstrinsik, masalah yang dihadapi dosen adalah kurangnya pelatihan ICT dan masalah koneksi internet. Kendala-kendala ini membuat para dosen menjadi berpikir dua kali dalam mengoptimalkan penggunaan ICT dalam kelas. Hasil penelitian ini dapat menjadi bahan evaluasi bagi dosen bahasa Inggris selaku pelaksana di lapangan dan bagi institusi sebagai pembuat kebijakan.
\end{abstract}

Kata kunci: persepsi, ICT, pembelajaran bahasa Inggris

\section{PENDAHULUAN}

Peran media dalam pembelajaran sangatlah penting karena dapat membantu tercapainya tujuan pembelajaran dengan efektif dan efisien. Media menjadi sarana pengganti, alat dimana di dalamnya mengandung pembelajaran yang sudah tersusun dan kemudian disampaikan kepada siswa (Clark: 2012). Walaupun ketika berbicara teknologi hal pertama yang tergambar dalam benak seseorang adalah komputer, akan tetapi teknologi pada dasarnya mencakup semua hal dari audio-tape player sampai ke video dan tentu saja komputer (Brown: 2001).

Pembelajaran bahasa kedua yang berbasis information and computer technology (ICT) dapat menurunkan masalah psikologis siswa dalam mengungkapkan opini dan dapat meningkatkan cara berpikir kritis, cara memecahkan masalah dan juga keterampilan berkomunikasi melalui 
aktivitas online atau class homepage construction (Young, 2003).

Politeknik Negeri Jakarta (PNJ) merupakan pendidikan tinggi vokasi yang menawarkan program Diploma Tiga dan Sarjana Terapan di bidang rekayasa dan tata niaga. Lulusan program D-3 mengisi bidang pekerjaan sebagai teknisi senior sedangkan lulusan program S-1 Terapan mengisi posisi profesional di perusahaan. Seiring dengan era globalisasi dan tuntutan industri yang lebih kompetitif, tuntutan lulusan PNJ pun semakin tinggi dalam penguasaan teknologi dan keterampilan berbahasa Inggris.

Keterampilan berbahasa Inggris adalah salah satu keterampilan yang harus dikuasai oleh mahasiswa politeknik yang tercantum dalam tujuan pembelajaran yang mengacu pada kurikulum Kerangka Kualifikasi Nasional Indonesia (KKNI). KKNI merupakan kurikulum yang mengitegrasikan bidang pendidikan dan pengalaman kerja untuk mengukur kualifikasi seseorang. Jenjang kualifikasi tersebut dituangkan dalam capaian pembelajaran di program studi. Salah satu kualifikasi yang diperlukan merupakan kompetensi berbahasa Inggris. Oleh karena itu, proses belajar mengajar bahasa Inggris diasumsikan sebagai faktor penting untuk mencapai kompetensi tersebut.

Dalam usahanya membekali mahasiswa PNJ mencapai kompetensi berbahasa Inggris, pimpinan dan unit bahasa PNJ pernah beberapa kali mengadakan pelatihan pengajaran bahasa Inggris dengan menggunakan ICT bagi para dosen bahasa Inggris PNJ. Melalui pelatihan ini, diharapkan di waktu yang akan datang para dosen dapat mengajarkan bahasa Inggris dengan memanfaatkan ICT yang ada agar pembelajaran dapat berlangsung efektif, efisien dan menyenangkan. Hal ini dibuktikan melalui pra-observasi yang dilakukan kepada rekan sejawat di lingkungan PNJ, di mana pembelajaran bahasa Inggris yang dilaksanakan dengan menggunakan ICT dapat meningkatkan motivasi belajar mahasiswa dan meningkatkan efisiensi waktu pembelajaran. Walaupun mengakui keefektifan ICT dalam pembelajaran bahasa Inggris, akan tetapi realisasinya tidak semua dosen menjadikan ICT sebagai media pembelajaran utama dalam pengajaran bahasa Inggris. Mereka lebih cenderung menggunakan media ICT standar yang biasa digunakan di kelas seperti laptop, infocus, dan email. Padahal para dosen tersebut sudah pernah mengikuti pelatihan pengajaran menggunakan ICT.

Berangkat dari fenomena tersebut, peneliti tertarik ingin melihat lebih jauh bagaimana persepsi para dosen bahasa Inggris terhadap penggunaan ICT dalam pembelajaran bahasa Inggris dan kendala apa saja yang mereka hadapi dalam menerapkan model pembelajaran ICT. Hal ini dianggap penting oleh peneliti agar nantinya dapat menjadi bahan evaluasi bagi dosen bahasa Inggris selaku pelaksana di lapangan dan bagi institusi sebagai pembuat kebijakan.

\section{METODE PENELITIAN}

Metode penelitian yang digunakan adalah metode kualitatif dengan data kuantitatif. Dalam proses pengumpulan data, penulis menggunakan dua perangkat penelitian berupa kuesioner, dan wawancara terhadap dosen bahasa Inggris di PNJ. Pengkajian ini dilakukan dengan mengumpulkan informasi terkait persepsi dosen terhadap penggunaan ICT, dan juga mengidentifikasi kendala dalam penggunaan ICT pada pembelajaran bahasa Inggris.

Tahap-tahap yang digunakan dalam pengumpulan data pada penelitian ini adalah (1) studi pustaka, (2) membuat kuesioner, mengujinya dan menyebarkannya kepada responden, (3) mencatat sumber data yang akan 
digunakan, menghitung persentase hasil survey melalui kuesioner, (4) melakukan wawancara terhadap responden, (5) mengklasifikasi data berdasarkan penguasaan dan pengalaman penggunaan ICT, tingkat kesukaran penggunaan ICT, permasalahan penggunaan ICT dalam pembelajaran bahasa Inggris..

\section{HASIL DAN PEMBAHASAN}

Klasifikasi data berdasarkan penguasaan dan pengalaman penggunaan ICT, tingkat kesukaran penggunaan ICT, permasalahan penggunaan ICT dalam pembelajaran bahasa Inggris

Berikut merupakan hasil survei dalam bentuk grafik yang telah diperoleh hingga saat ini

1. Kegunaan ICT

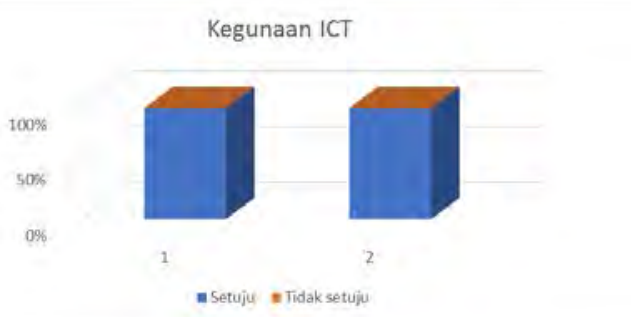

Pada bagian ini, berdasarkan grafik di atas, seluruh responden menyatakan bahwa pengajaran Bahasa inggris sangat cocok dipadukan dengan ICT. Selain dapat memberikan ruang untuk dosen berinovasi, penggunaan ICT juga dapat membuat pembelajaran menjadi sangat menyenangkan

2. Kemudahan Penggunaan ICT

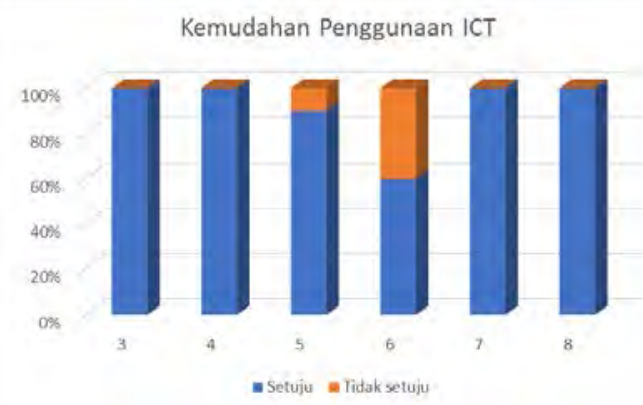

Pada bagian yang kedua ini, yaitu dalam konteks kemudahan dalam penggunaan ICT. Berdasarkan grafik diatas, semua responden menyatakan setuju dengan kemudahan yang didapatkan saat menyiapkan materi pengajaran, penggunaan ICT dalam pengajaran, penggunaan internet dan penggunaan computer. Namun beberapa dosen menyatakan ketidaksetujuaannya dalam penggunaan ICT dalam berbagi pengalaman mengajar dan melatih seseorang dalam pembelajaran Bahasa inggris dengan menggunakan ICT.

3. Kegunaan Bagi Mahasiswa

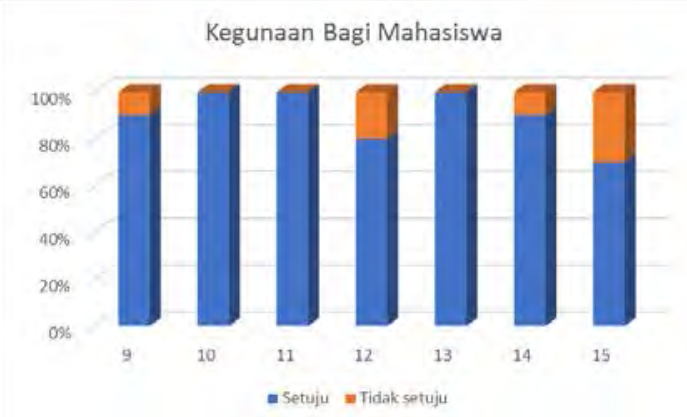

Pada bagian kegunaan bagi mahasiswa, beberapa dosen tidak setuju dengan manfaat pengajaran ICT yang akan mempermudah mahasiswa dalam mendapatkan pekerjaan (yang layak) dimasa yang akan datang. Selain itu juga, beberapa pengajar juga tidak setuju bahwa pembelajaran menggunakan ICT dapat membantu mahasiswa memahami materi secara mendalam, kemudian meningkatkan nilai Bahasa inggris, dan membantu mahasiswa dalam berkomunikasi.

4. Kegunaan Bagi Dosen

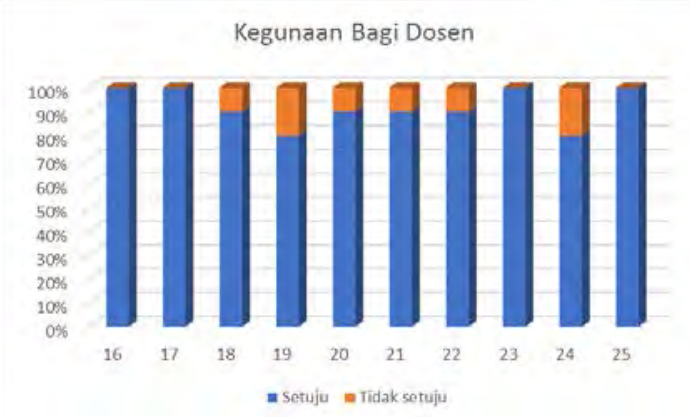

Pada bagian ini dosen setuju bahwa adanya kemudahan dalam mengakses bahan atau materi pengajaran Bahasa inggris dari internet dan materi pengajaran menggunakan ICT dapat digunakan secara berulang-ulang. Selain itu, semua dosen Bahasa inggris di PNJ juga telah menggunakan ICT 
dalam pengajaran Bahasa inggris dikampus.

5. Kendala Penggunaan ICT (faktor intrinsik)

Kendala Penggunaan ICT 1

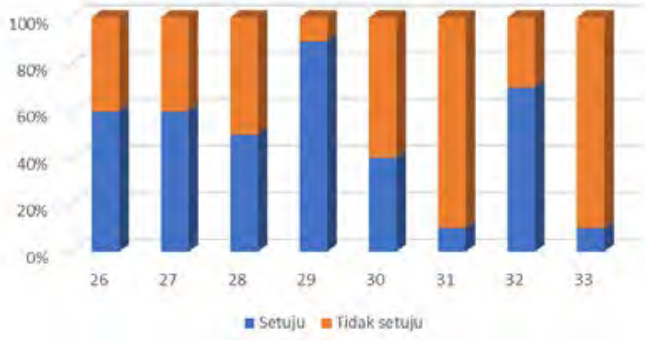

6. Kendala Penggunaan ICT (faktor ekstrinsik)

Kendala Penggunaan ICT 2

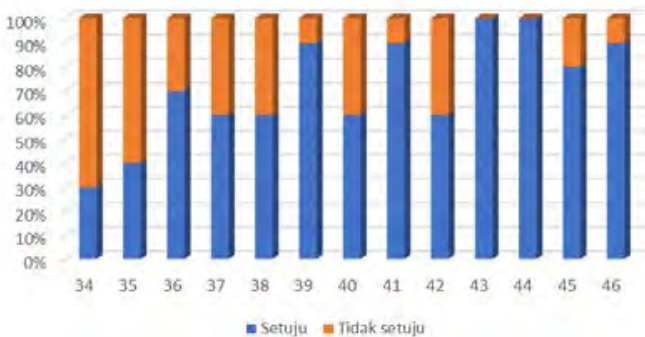

Berdasarkan informasi dari responden, terlihat masih banyaknya kendala dalam penggunaan ICT di PNJ. Kendala-kendala tersebut antara lain berhubungan dengan fasilitas yang ada di kampus dan kurangnya dukungan dari pimpinan. Selain itu beberapa dosen juga masih merasa bahwa penggunaan ICT malah menambah beban kerja mereka.

\section{KESIMPULAN DAN SARAN}

Berdasarkan hasil survei yang telah dilakukan, didapatkan informasi bahwa seluruh responden yang merupakan dosen menyatakan bahwa pengajaran bahasa Inggris sangat cocok dipadukan dengan ICT. Menurut para responden, ICT, selain dapat memberikan ruang untuk dosen berinovasi, kemudahan dalam menyiapkan materi pengajaran, penggunaan ICT juga dapat membuat pembelajaran menjadi sangat menyenangkan.

Terkait kegunaan ICT bagi Mahasiswa, beberapa dosen tidak setuju dengan manfaat pengajaran ICT yang akan mempermudah mahasiswa dalam mendapatkan pekerjaan (yang layak) dimasa yang akan datang. Selain itu juga, beberapa dosen juga tidak setuju bahwa pembelajaran menggunakan ICT dapat membantu mahasiswa memahami materi secara mendalam, kemudian meningkatkan nilai bahasa Inggris, dan membantu mahasiswa dalam berkomunikasi.

Penggunaan ICT dalam pembelajaran bahasa Inggris selama ini telah didukung oleh institusi. Namun, terdapat beberapa kendala ditemukan secara intrinsic dan ekstrinsik. Definisi kendala intrinsik merupakan kendala yang terjadi pada dosen, administrator, dan individu. Sedangkan kendala ekstrinsik merupakan kendala yang terjadi pada organisasi (atau institusi). Kendala yang dialami dosen paling besar merupakan kompetensi dosen dalam menggunakan ICT sekaligus juga pengalaman-pengalaman buruk yang pernah dialami dosen dalam penggunaan ICT dalam kelas. Pada kendala ekstrinsik, masalah yang dihadapi dosen adalah kurangnya pelatihan ICT dan masalah koneksi internet. Kendala-kendala ini membuat para dosen menjadi berpikir dua kali dalam mengoptimalkan penggunaan ICT dalam kelas.

\section{DAFTAR PUSTAKA}

Brown, H. Douglas. 2001. Teaching by Principles: An Interactive Approach to Language Pedagogy. New York: Addison Wesley Longman

Clark, Richard. E. 2012 Learning from Media: Arguments, Analysis and Evidence. North Carolina: Information Age Publishing. 
Darmawan, Deni. 2012. Pendidikan Teknologi Informasi dan Komunikasi Teori dan Aplikasi. Bandung: Remaja Rosdakarya.

Etriyanto, et.al . "Peran Teknologi Informasi dan Komunikasi Dalam Meningkatkan Kualitas Pendidikan. https://bdkpadang.kemenag.go.id/index .php?option=com_content $\&$ view=articl e\&id=745:etriyantofeb\&catid=41:topheadlines\&Itemid=158

Hardjito. 2002. Internet untuk Pembelajaran. (online). Tersedia: http://www.pustekkom.go.id/teknodik/t -10/10-3.html. di akses 15 November 2016.

Surjono, Herman Dwi. 2013. "Peranan Teknologi Informasi dan Komunikasi (ICT) dalam Peningkatan Proses Pembelajaran yang Inovatif”. Seminar Nasional Pendidikan \& Saintec di UMS.

Rusman, dkk. 2011. Pembelajaran Berbasis Teknologi Informasi dan Komunikasi. Jakarta: Rajagrafindo Persada.

Suprapto. 2006. Peningkatan Kualitas Pendidikan Melalui Media Pembelajaran Menggunakan Teknologi Informasi di Sekolah, Jurnal Ekonomi dan Pendidikan, Vol. 3.1. 2006. 
Sari Puspita D, Abdul Azis A, Nidia Sofa Persepsi Dosen Terhadap... 